\title{
An Ethnographic Investigation of Creativity In Practicing Visual Artists/Teachers: A Conceptual Paper
}

\section{Susan Dodson}

I live of my dying, and considering it well, I live happily in my unhappy state

And he who knows not how such anguish is possible Let him enter the fire with me, and be consumed by fate. Michelangelo Buonarroti

Michelangelo's words burn with the passion of a person totally consumed by the creative spirit. His words crackle across the centuries, challenging us to be awake.

Be awake to what? To authenticity. To meaning. To becoming human. To creativity-- to the artist within.

Creativity can unfold into a tapestry of transformation. Like the tapestry, creativity confronts and engages us with multiple strands that rise to the surface only to disappear again in the mysterious labyrinth before us. We see evidence of the interconnection of all the singular threads; we recognize that chaos has been transiormed into order, weaving a visual harmony, a unified whole. This process of creativity, transforming concepts, ideas, and thoughts into concrete realities is an integral part of meaninglul learning.

Transformation, in this context, refers to a multi-dimensional creative thought process that results in an expansion of an individual's thoughts and awareness such that life is experienced more holistically. Creative engagement becomes more meaningful and relevant to everyday life. This enlargement of consciousness likewise enlarges meaning for the individual through a creative thought process that is not observable, but whose outcome may be observable. The quiet connections that lie beneath the surface of forming and transforming through creative engagement pose a web of questions. What are the connections? How do they occur? What does transformation, or personally significant growth, mean in the context of creative endeavor? How is it experienced? What external and internal conditions encourage it? How does a practicing artist who is an educator effectively foster creativity and such significant learning experiences through 
art? How can an artist/educator most effectively elicit the whole person using paint, pastels, clay, and other media?

The primary purpose of this study is to investigate the nature of creativity and the creative process in the visual arts. The study explores select phenomena of creative endeavor in the lives of three artists who also teach. These phenomena include how creativity functions in the artists' lives-including teaching; how creativity interacts with self-perception and life experiences; and how creativity is encouraged by these artist-teachers in the college classroom.

Questions of the inquiry evolved from personal experience after studying with Peter London and Seymour Segal at the University of Massachusetts, N. Dartmouth, in 1990 . This proved to be a turning point in my own awareness of the power of imagery and creativity in relationship to centeredness and connectedness. I observed the potential and experienced the impact of the creative process as a beneficial and personally transforming phenomenon; since then, I have wanted to understand the dynamics better, to encourage my students to grow in more integrated and meaningful ways, and to advance research on this subject in art education.

Course objectives, in the studies with London and Segal, included a wide variety of guided imageries, followed by specifically focused art expressions; these experiences concluded with discussion, either in smail groups or the whole class. The discussions encouraged reflection, synthesis, clarification, and understanding of self and one another. Students, mostly older adults, were invited to participate. The only rule was that we suspend judgment and quiet any inner critical voices.

The suspension of judgment allowed the adult participant, long familiar with constraints of convention, to experiment, to express, to risk, and to grow. The physical, mental, and verbal creative processes, in total, fostered several significant learning experiences: (a) honesty with self; (b) a deeper grasp of meaning in life, within and beyond the self; (c) a more acute awareness of wholeness, of connectedness with life; and (d) greater openness to one's creativity. The totality of this unique experience was integrative, holistic, and transformative, to varying degrees.

I not only have observed these positive energies as a student but also as a college art teacher. One class was a particularly challenging mix of students, and included two women acting out rebellion; two extremely shy and docile women; a very outspoken opinionated man; and a former construction worker whose reputation had been built on street fighting. This group did not congeal well; rather, they argued vehemently. These dynamics 
clearly called for objectives to facilitate better communication and attitudes, and clearer personal meaning of content.

These objectives were approached by combining several guidedimagery and hands-on exercises with reflective discussion. One exercise, from Peter London's book, No More Secondhand Art, was particularly beneficial to the class, " Random Acts of Kindness, Senseless Gifts of Beauty" (1989, p. 162). This encounter asked participants to recall kindness shown to them, to meditate on this, and then express these experiences on paper with paints. Although reflective discussion was optional, the class chose to share their images and meanings. The transforming energy described previously became evident in my own students. Class members stopped biting at each other and began genuine dialogue that enhanced learning. The two rebellious women talked openly about their selfdestructive behaviors and how our creative activities moved them toward greater honesty. The shy students took more active roles, and the outspoken "challenger of all viewpoints" began to mellow and listen. Such shifting dynamics appeared to be a small miracle.

Another change occurred that further supported the question of art as a holistic and transformative engagement. As students began painting for the "Random Acts of Kindness" engagement, the "street-fighter" individual briskly left the room in a decidedly "no-thanks" attitude. I encountered him in the hall, where he stated that "acts of kindness and gratitude were no one else's business." I invited him to step into the jewelry room to talk. As we talked, he shared about loved ones who had been kind. His clenched jaws relaxed and his whole demeanor changed as he remembered the touch of his grandfather. While continuing, he picked up a wire and began twisting it, looking at me most of the time. When our talk ended, he handed me the wire, saying it was a "little gift." $\mathrm{He}$ had beautifully formed the wire into the word "Life." He had not only participated, but had experienced some degree of positive change. As London states, "Art is not only pretty, Art is Power. Power not only to transform the face of the page , but the quality of our lives" (1991, March).

Art, like life, is a gift--a deep and vastly rich tapestry of expression and meaning. Inherent within the gift are many invitations to us, as both creators and recipients of life and art, to meaningfully participate in the creative process. We, as art educators, have unique opportunities to facilitate such creative engagement, thereby helping to enrich and elevate life for our students. This means encouraging students to explore beyond the surface of decoration, formal analysis, art as object, and art as entertainment, to experience connection with life and life-giving sources. The spirit of art 
invites us to be authentic and fully human, a particular challenge in contemporary western life.

We live in an age saturated with competitive, materialistic, and mechanistic attitudes; consequently, life is largely fragmented and secularized. Teachers, being products of contemporary life, cannot help but reflect current cultural values, to some degree, in the classroom. The creative encounter that results in art, inadvertently then, can be reduced to a commodity, a novelty, a form of entertainment--merely an object. Henri (1984) states that, 'One of the curses of art is 'Art.' This filling up of things with 'decoration,' with by-play, to make them beautiful" (p. 204). Is it any surprise that creative engagement and its resulting art are often perceived as peripheral and irrelevant to valued and meaningful experience?

The creative encounter, in the form of art is not, however, peripheral, irrelevant, or outside of ordinary or even, extraordinary, experience. Art and the creative process are closely connected to real life, as demonstrated by the theoretical framework for this research. The framework is comprised of writings by Martin Buber and Rollo May. The study's central focus deals with the connection of creativity to everyday life. Buber's holistic philosophy encompasses the total theoretical framework in that he addresses the creative person in the larger context, in relation to human and spiritual life. Rollo May's philosophy parallels that of Buber, but with more attention to specific stages of the creative process.

Buber distinguishes between the world of experience, "F- it," and that of relation, "I-Thou." The world of relation involves three spheres: our life with nature, with human beings, and with spiritual beings (p. 6). Central to his thinking is the concept of "I-Thou," which implies an attitude of respect for and acceptance of ourselves and all life. Buber's living mutual relation and genuine dialogue "elevate the quality of life to a preferred state" (London, 1989 , p. 8). The result of genuine dialogue is that "the other is affirmed as what he really is, and thus he is confirmed as a creature" (Smith, 1967, p. 27). As Buber succinctly states," All real living is meeting" (1958, p.11). All of life is infused with grace, through which we can experience wholeness and harmony.

In contrast, the world of experience encompasses an attitude of objectifying life, human beings and nature alike; Buber refers to this as "I-It." The "I-It" mindset dehumanizes and despiritualizes life, and thus, diminishes creativity. Buber states, "If I face a human being as my Thou'... he is not a thing among things, and does not consist of things" (1958, p. 8). Moreover, a person needs a certain receptiveness in order to grow, one that cannot be forced. Buber says, "The Thou meets me through grace--it is not found by 
seeking. But my speaking of the primary word, it is an act of my being, is indeed the act of my being" (1958, p.11).

Buber relates this essential act of being to the creative process of art. The process of forming an image of the relation between human beings flames the power of art. Buber clarifies that "It is not the image taken from the mind of the artist (the 1) or from the other he portrays (the Thou), but of that which occurs in the encounter" (Kohanski, 1975, p.156). Thus, Buber posits that the essence of art represents relationship, the "image of the between...neither the mystery of the things nor that of the spirit...but the relation between the two" (Kohanski, 1975, p.156).

More specifically, Buber distinguishes between two classes of relation that humans establish with the environment, other humans, and with objects (Cohen, 1983, p.203) . Buber refers to one kind of relation as "realization" and the other as "orientation."

The orienting person, in relation to the creative process, is primarily interested in tangible benefits and advancement opportunities as opposed to it's intrinsic values. As such, creativity is sought for profit and gain. Thus, art becomes a commodity. Buber describes orienting persons as failing to realize experience wholly. He states, "Theirs is a substitute for life, a surface existence in which life's substance is exchanged for it's husk, to which they apply the elegant epithets of culture, religion, progress, tradition, and intellectuality" (Cohen, 1983, p. 205).

By contrast, realizing persons embrace the creative process and art for their intrinsic values, and they experience these with all their senses. Buber explains that realization" has to do with those situations of exalted experience in life that arise in moments of intense experience and perception [and that] here we have the source of the creativity and daring of the human spirit" (Cohen, 1983, p. 204). Buber believes that the faculty of realization is strongest in the creative person, "in whom the soul's capacity to realize reaches such a pitch of concentrated energy that he creates reality for everyone" (Cohen, p. 204). Buber acknowledges that realization cannot operate all the time; simply being human prevents this. Even the most creative persons alternate between orienting and realizing, with moments of full realization being those in which the spirit feels joy and is exalted. These moments are of course, followed by moments of orientation.

Buber's concept of the creative person finds support irom May's insightful book, The Courage to Create. Creativity requires courage. Courage, requiring a centeredness within one's being, is the capacity to move ahead in spite of despair $(1980$, p. 3$)$. To illustrate, May describes 
Cezanne, who, knowing his paintings to be of a major significance, was haunted by constant and painful self-doubt; yet Cezanne pushed on in spite of doubt and strong discouragement. May succinctly states, "Commitment is healthiest when it is not without doubt, but in spite of doubt" (p. 14).

May proposes four elements to his theory of creative process. First, the creative act is an encounter. For example, the artist may encounter a landscape, an idea, or an inner vision, which may or may not involve voluntary effort. In contrast, "escapist creativity is that which lacks encounter" (p. 40) . The second element is intensity or absorption, having heightened consciousness, and being wholly involved in the creation. The creator often experiences joy, relerred to as exalted spirit by Buber, originating from the experience of actualizing one's potentialities (pp. 44, 45). The third element is purpose, which involves all levels of creative experience. We can will to give ourselves to the encounter with commitment (p. 46). The fourth element of creative encounter is ecstasy. This describes those rare hoilstic moments when the subconscious and unconscious unite with the conscious to produce a "suprarational" experience (p. 49). Ecstasy involves the total person, and to a degree, heals the split between subject and object so typical of Western thought and activity (p. 49).

The role of unconscious dimensions of experience is integral to May's theory, particularly as the source for the creator's breakthrough ideas. The predominant feelings from breakthrough area are gratification and joy. Such insight is not random, but comes in accordance with a pattern determined by commitment and conscious effort. Part of that effort requires solitude. Purposeful separation from the forever intruding world is essential to the artist. Solitude allows insights from the unconscious to emerge. When a breakthrough does occur, it tends to strike the creator as true. The artist glimpses a new reality, and such an experience may have a spiritual quality. May finds that many artists "feel that something holy is going on when they paint, that there is something in the act of creating which is like a religious revelation" (1980. p.75) .

Summarily, May proposes that the artist's "passion for form is a way of trying to find and constitute meaning in life. And this is what genuine creativity is" (1980, p.161). Likewise, we as art educators have important choices to make regarding the quality of instruction and role modeling for students. The education we offer will have greater relevance and meaning if guided by a larger, more inclusive, and compassionate vision of all life, such as found in Buber's concept of "I-Thou." 


\section{References}

Alexander, S. (Trans.). (1991). The Complete Poetry of Michelangelo. Athens: Ohio University Press.

Arieti, S. (1976). Creativity: The Magic Synthesis. New York: Basic Books, Inc..

Barron, F. (1969). Creative Person and Creative Process. New York: Holt Rinehart and Winston, Inc..

Cohen, A. (1983). The Educational Philosophy of Martin Buber. New Jersey: Associated University Presses, Inc.

Gardner, H. (1982). Art, Mind \& Brain: A Cognitive Approach to Creativity. New York: Basic Books, Inc..

Getzels, J. \& Csikszentmihalyi, M. (1976). The Creative Vision: A Longitudinal Study of Problem Finding in Art. New York: John Wiley \& Sons.

Goodman, L. (1981. Death and the Creative Life. New York: Springer Publishing.

Henri, R. (1984). The Art Spirit. New York: Harper \& Row.

Kirby, D. \& Kuykendall, C. (1991). Mind Matters: Teaching For Thinking. New Hampshire: Boynton/Cook Publishers.

Kohanski, A. (1975). An Analytical Interpretation of Martin Buber's I-Thou. New York: Barron's Educational Series Press.

London, P. (1989). No More Secondhand Art: Awakening the Artist Within. Boston: Shambhala Press.

London, P. (1991, March). Art as Transformation. Paper presented at the National Art Education Association Annual Convention, Atlanta, GA.

May, R. (1980). The Courage to Create. New York: Bantam Books.

McLuhan, T. (1971). Touch the Earth. New York: Outerbridge \& Diensttrey. 
Melrose, L. (1989). The Creative Personality and the Creative Process. New York: University Press of America.

Owen, R. (1982. The Creative Personality and the Creative Process. New York: School for Social Research. Dissertation Abstracts International, 44, 04B, 1223.

Smith, R. (1967). Martin Buber. Richmond: John Knox Press.

Sudnow, D. (1978). Ways of the Hand. New York: Harper and Row.

Zinker, J. (1977). Creative Process in Gestalt Therapy. New York: Vintage Books. 